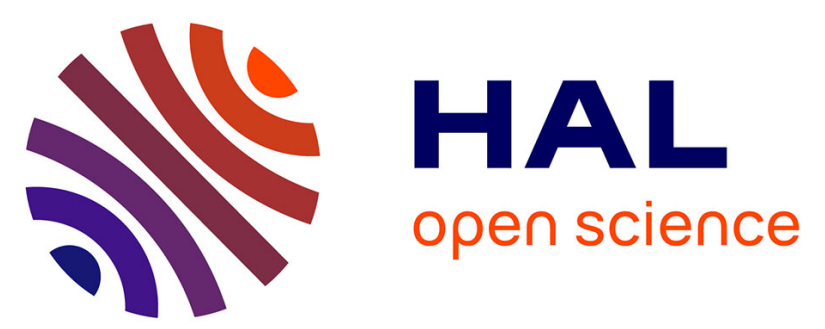

\title{
Conditional expression of Ki-RasG12V in the mammary epithelium of transgenic mice induces estrogen receptor alpha $(\mathrm{ER} \alpha)$-positive adenocarcinoma
}

Sebastiano Andò, Rocco Malivindi, Stefania Catalano, Pietro Rizza, Ines Barone, Salvatore Panza, Daniela Rovito, Camille Emprou, Jean-Marc

Bornert, Gilles Laverny, et al.

\section{To cite this version:}

Sebastiano Andò, Rocco Malivindi, Stefania Catalano, Pietro Rizza, Ines Barone, et al.. Conditional expression of Ki-RasG12V in the mammary epithelium of transgenic mice induces estrogen receptor alpha (ER $\alpha$ )-positive adenocarcinoma. Oncogene, 2017, 36 (46), pp.6420-6431. 10.1038/onc.2017.252 . hal-03551145

\author{
HAL Id: hal-03551145 \\ https://hal.science/hal-03551145
}

Submitted on 1 Feb 2022

HAL is a multi-disciplinary open access archive for the deposit and dissemination of scientific research documents, whether they are published or not. The documents may come from teaching and research institutions in France or abroad, or from public or private research centers.
L'archive ouverte pluridisciplinaire $\mathbf{H A L}$, est destinée au dépôt et à la diffusion de documents scientifiques de niveau recherche, publiés ou non, émanant des établissements d'enseignement et de recherche français ou étrangers, des laboratoires publics ou privés. 


\section{Conditional expression of Ki-Ras ${ }^{\mathrm{G12}}$ in the mammary epithelium of transgenic mice induces estrogen receptor alpha $(\mathrm{ER} \alpha)$-positive adenocarcinoma}

Sebastiano Andò ${ }^{1,2, *}$, Rocco Malivindi ${ }^{1}$, Stefania Catalano ${ }^{1}$, Pietro Rizza ${ }^{1}$, Ines Barone ${ }^{1}$, Salvatore Panza $^{1}$, Daniela Rovito ${ }^{1,3}$, Camille Emprou ${ }^{3}$, Jean-Marc Bornert ${ }^{3}$, Gilles Laverny ${ }^{3}$, Daniel Metzger $^{3, *}$

\section{Author Affiliations:}

${ }^{1}$ Department of Pharmacy, Health and Nutritional Sciences, ${ }^{2}$ Centro Sanitario, University of Calabria, Arcavacata di Rende (CS), 87036, Italy; ${ }^{3}$ Institut de Génétique et de Biologie Moléculaire et Cellulaire (IGBMC), Department of Functional Genomics and Cancer, Institut National de Santé et de Recherche Médicale (INSERM) U964/Centre National de Recherche Scientifique (CNRS) UMR 7104/Université de Strasbourg, 67404 Illkirch, France.

Running Title: Mammary adenocarcinomas in Ki-Ras transgenic mice

\section{*Correspondence and requests should be addressed to:}

Daniel Metzger, Institut de Génétique et de Biologie Moléculaire et Cellulaire (IGBMC), Department of Functional Genomics and Cancer, Institut National de Santé et de Recherche Médicale (INSERM) U964/Centre National de Recherche Scientifique (CNRS) UMR 7104/Université de Strasbourg, 67404 Illkirch, France Phone: +33388653463/Fax +33388653201, email: metzger@igbmc.fr

Sebastiano Andò, Department of Pharmacy, Health and Nutritional Sciences, Edificio Polifunzionale, via P Bucci, University of Calabria, Arcavacata di Rende (CS), 87036, Italy, Phone: +390984496201-3109/Fax: +390984496203, email: sebastiano.ando@unical.it

Funding support: This work was supported by: Fondazione Italiana per la Ricerca sul Cancro (AIRC) grants: IG \#11595 (S. Andò), MFAG \#16899 (I. Barone), PROGRAMMA "FUTURO IN RICERCA" Anno 2012 \#RBFR12FI27 (I. Barone), Fellowships for Abroad \#19552 (D. Rovito), EMBO ASTF\#18-2010 (R. Malivindi), European Social Fund operational programme of the Calabria region (S. Panza), Faculté de Médecine, Université de Strasbourg (C. Emprou) and by the Centre National pour la Recherche Scientifique (CNRS), the Institut National de la Santé et de la Recherche Médicale (INSERM), the Université de Strasbourg and French state funds through the Agence Nationale de la Recherche ANR-10-LABX-0030-INRT under the frame programme Investissements d'Avenir labelled ANR-10-IDEX-0002-02. 


\begin{abstract}
Appropriate 'in vivo' models are crucial for studying breast cancer biology and evaluating the efficacy of therapeutic agents. Thus, we engineered a novel transgenic mouse line expressing the human Ki-Ras bearing an activating mutation (Ki-Ras ${ }^{(\mathrm{G} 12 \mathrm{~V})}$ ) selectively in the mammary epithelium after lactation. These mice develop invasive ductal adenocarcinomas with $100 \%$ incidence within 3

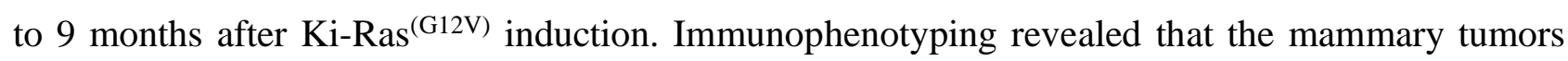
express luminal markers, are positive for estrogen and progesterone receptors, negative for HER2, and have a low proliferation index. Moreover, cell lines derived from such tumors are estrogenresponsive, and when transplanted into nude mice, form tumors that respond to the antiestrogen ICI 182780. In conclusion, the mammary tumors of these transgenic mice and the derived cell lines exhibit key features of the major form of human breast cancer, i.e. luminal A subtype, and thus have a high potential for breast cancer research and treatment.
\end{abstract}

Key Words: Ki-Ras, mammary gland; carcinogenesis; estrogen receptor; luminal breast tumors. 


\section{Introduction}

Breast carcinoma is the most common malignancy and the leading cause of cancer-related death in women worldwide. Breast cancer is a complex and highly heterogeneous disease characterized by distinct morphologic features, variable clinical outcomes and disparate therapeutic responses. Studies based on global gene expression analyses have classified breast cancer into at least five biologically distinct intrinsic subtypes, including luminal A, luminal B, human epidermal growth factor receptor 2 (HER2)-enriched, basal-like, and normal-like. ${ }^{1,2}$ Luminal A and B subtypes, referred to as estrogen receptor (ER) $\alpha$ positive, represent $\sim 70 \%$ of breast cancers, and thus are of major clinical interest.

Several genetically modified mouse models (GEMMs) have been generated for mechanistic and therapeutic studies of mammary tumors. The first reported transgenic mouse model of breast cancer was the mouse mammary tumor virus (MMTV)-myc model, in which overexpression of the myc transcription factor in the mammary gland resulted in spontaneous mammary adenocarcinoma. ${ }^{3}$ In addition, various promoters have been used to drive the expression of transgenes in the mammary epithelium, including $\mathrm{ErbB} 2 / \mathrm{Neu}$, polyoma middle $\mathrm{T}$ antigen $(P y M T)$, simian virus $40 \mathrm{~T}$ antigen (SV40T), wnt-1, TGF- $\alpha, c-m y c$ and ras $^{4-9}$. Although these mouse models develop mammary carcinomas, they are prevalently ER $\alpha$-negative and hormone-independent, and thus do not mimic luminal subtypes.

In human cancers, the most frequently mutated dominant-acting oncogenes are the ras genes. Among them, Harvey (Ha)-, Kirsten (Ki)-, and N- ras genes encode four highly homologous 21$\mathrm{kDa}$ GTP-binding proteins, Ha-Ras, Ki4A-Ras, Ki4B-Ras, and N-Ras, which regulate the transduction of growth promoting signalings from the membrane to the nucleus. ${ }^{10}$ Whereas genetic ablation of either N-ras or H-ras is compatible with normal development, homozygous Ki-ras-null mutant embryos succumb in utero, ${ }^{11-13}$ suggesting that Ki-Ras is the most important isoform for controlling developmental programs. Exon 2 mutations at the codon 12 and 13 are the most common Ki-Ras mutations in human cancers and therefore may mirror adequately the human disease. ${ }^{14}$ Omer et al. have developed MMTV-Ki-Ras ${ }^{(\mathrm{G} 12 \mathrm{~V})}$ transgenic mice, which express the oncogenically mutated human Ki-Ras ${ }^{(\mathrm{G} 12 \mathrm{~V})}$ transgene under the control of the MMTV promoter. ${ }^{15}$ They develop mammary adenocarcinoma with a short tumor latency, high tumor incidence and readily measurable tumor burdens that allow to monitor tumor volume over time. Although this mouse model has shed light into breast carcinogenesis, it suffers from a number of limitations, such as tumor formation in various tissues, including salivary and harderian glands, as well as the lack of immunophenotypic characterization of mammary carcinomas. 
Targeted somatic mutagenesis systems based on tissue- or cell-specific expression of the bacteriophage P1 Cre recombinase, which excises LoxP-flanked (floxed) DNA segments, have been developed. ${ }^{16-18}$ In particular, the use of the Cre/LoxP system enabled to overcome the limits of conventional gene targeting approaches through temporal and tissue-specific control over gene expression. Based on the tissue specificity of the promoter driving Cre expression, tumors develop at selected anatomical sites in progeny generated by mating Cre-producers with mice carrying a dormant oncogenic transgene that becomes functional after excision of a floxed DNA segment blocking its expression. Using the Cre/LoxP system, mammary gland-specific overexpression of the constitutively active oncogenic mutant Ki-Ras ${ }^{(\mathrm{G} 12 \mathrm{D})}$ has been successfully obtained. ${ }^{19}$ This model was associated with the development of histopathologically heterogeneous malignant tumors, predominantly simulating human basal-like breast cancers.

In the present study, we have generated transgenic mice carrying the mutated human $\mathrm{Ki}_{\text {-ras }}^{(G 12 \mathrm{~V})}$ oncogene under the control of the MMTV-long terminal repeat (LTR) promoter, and in which a LoxP flanked stop cassette is located between the MMTV-LTR promoter and the $\mathrm{Ki}_{\text {-ras }}^{(G 12 \mathrm{~V})}$ coding sequence. Expression of Ki-Ras ${ }^{(\mathrm{G} 12 \mathrm{~V})}$ has been induced in mammary tissue during lactation by Cre recombinase expressed under the control of the ovine beta lactoglobulin promoter (BLGCre). Our results show that these transgenic mice develop, within a period of 3 to 9 months after lactation, ductal ER $\alpha$-positive adenocarcinomas exhibiting features of luminal breast cancers in humans. Cell lines isolated from such tumors show characteristics that are highly concordant with the molecular features found in the primary tumors, are estrogen-responsive and transplantable. Thus, the mouse model reported here can be added to the spectrum of available genetically engineered mice, as a valuable research tool for advancing our understanding of breast cancer biology and studying therapeutic responses. 


\section{Results}

Generation of mice expressing $\mathrm{Ki}^{-\operatorname{Ras}^{(G 12 V)}}$ selectively in the mammary epithelium after lactation.

To allow conditional Ki-Ras ${ }^{(\mathrm{G} 12 \mathrm{~V})}$ expression in mammary epithelium, we generated C-Ki$\operatorname{Ras}^{(\mathrm{G} 12 \mathrm{~V})}$ transgenic mice that express, after Cre-mediated DNA recombination, $\mathrm{Ki}^{-\mathrm{Ras}}{ }^{(\mathrm{G} 12 \mathrm{~V})}$ under the control of the mammary tumor virus long terminal repeat (MMTV-LTR) promoter. To this end, a LoxP-flanked Enhanced Green Fluorescent Protein (EGFP) stop cassette was cloned between the MMTV-LTR and the human Ki-Ras coding sequence containing an activating mutation in codon 12 (Gly to Val) (Ki-Ras $\left.{ }^{(\mathrm{G} 12 \mathrm{~V})}\right)$ to generate the MMTV-LoxP-EGFP-LoxP-Ki-Ras ${ }^{(\mathrm{G} 12 \mathrm{~V})}$ transgene. Microinjection of this transgene into fertilized eggs resulted in 6 transgenic founder mice, 3 of which transmitted the transgene through the germ line, termed hereafter $\mathrm{C}-\mathrm{Ki}-\mathrm{Ras}^{(\mathrm{G} 12 \mathrm{~V})} 09,40$ and 42. To induce Ki-Ras ${ }^{(\mathrm{G} 12 \mathrm{~V})}$ expression in the mammary epithelium, mice from each line were bred with BLG-Cre transgenic mice that express Cre under the control of the ovine beta lactoglobulin promoter, which is highly selective to mammary epithelial cells during pregnancy and lactation ${ }^{20}$ (Figure 1a). Virgin bigenic female BLG-Cre/C-Ki-Ras ${ }^{(\mathrm{G} 12 \mathrm{~V})}$ mice of the 3 lines developed normally without abnormalities of the mammary gland and other tissues (Supplementary Figure 1a and data not shown). Moreover, alveologenesis and lactogenic differentiation of the mammary gland occurred during pregnancy and post-partum in BLG-Cre/C-Ki-Ras ${ }^{(\mathrm{G} 12 \mathrm{~V})}$ mice (Supplementary Figure 1a and data not shown).

PCR analyses revealed that the floxed EGFP stop cassette was efficiently excised in the mammary glands of BLG-Cre/C-Ki-Ras ${ }^{(\mathrm{G} 12 \mathrm{~V})}$ during and after lactation, while no BLG-Cre-mediated recombination was detected in any other organs, including uterus, ovary, lung, salivary gland, harderian gland, and ear (Supplementary Figure 1b and data not shown). As expected, the EGFP stop cassette was PCR-amplified in all examined tissues, but at lower levels in mammary glands, reflecting Cre-mediated DNA excision in this tissue (Supplementary Figure 1b and data not shown). In contrast, no recombination was detected in the mammary glands of virgin BLG-Cre/C-Ki$\operatorname{Ras}^{(\mathrm{G} 12 \mathrm{~V})}$ at 10 and 58 weeks of age (Supplementary Figure $1 \mathrm{~b}$ and data not shown). Palpable mammary tumors developed around 20 weeks after lactation in BLG-Cre/C-Ki-Ras ${ }^{(\mathrm{G} 12 \mathrm{~V})}$ mice established with line 42 (termed MG-Ki-Ras $\left.{ }^{(\mathrm{G} 12 \mathrm{~V})}\right)(\mathrm{n}=12)$, but only after more than 40 weeks in mice from lines $09(n=5)$ and $40(n=14)$. Thus, line 42 was selected for further studies.

\section{Tumor development in MG-Ki-Ras ${ }^{(G 12 V)}$ mice.}

To further characterize MG-Ki-Ras ${ }^{(\mathrm{G} 12 \mathrm{~V})}$ mice, tumor development was followed in 48 females. All mice developed mammary tumors within a period of 3 to 9 months after the start of lactation 
(Figure 1b). Nearly $30 \%$ of them displayed multiple tumors (2-5), localized in various mammary glands with a higher prevalence in the axillary area, followed by the cervical area. In contrast, all virgin BLG-Cre/C-Ki-Ras ${ }^{(\mathrm{G} 12 \mathrm{~V})}$ female mice $(\mathrm{n}=17)$ remained tumor-free beyond 50 weeks (data not shown). qRT-PCR analysis revealed high transcript levels of human $\mathrm{Ki}-\operatorname{Ras}^{(\mathrm{G} 12 \mathrm{~V})}$ in mammary tumors, whereas they were undetectable in the mammary gland of virgin BLG-Cre/C-Ki-Ras ${ }^{(G 12 V)}$ female mice (Figure 1c). Moreover, immunoblotting showed that the total Ki-Ras levels were about 3.5 fold higher in the neoplastic tissue of MG-Ki-Ras ${ }^{(\mathrm{G} 12 \mathrm{~V})}$ mice than in control mammary glands (Figure 1d).

\section{Histology and immunophenotyping of $\mathrm{Ki}_{-\operatorname{Ras}^{(\mathrm{G12})}}$-induced mammary tumors.}

All MG-Ki-Ras ${ }^{(\mathrm{G} 12 \mathrm{~V})}$ tumors were well encapsulated within the mammary gland without skin ulceration or abdominal wall invasion. Metastasis to the lung, liver and lymph nodes were not macroscopically observed. Histopathological analysis of tumors arising in MG-Ki-Ras ${ }^{(\mathrm{G} 12 \mathrm{~V})}$ mice revealed the development of invasive ductal adenocarcinomas, from low to high grade of malignancy, with a cytology including prominent nucleoli and relatively open chromatin, similar to human invasive ductal adenocarcinomas. Some structural maturation toward the center with peripheral larger and more proliferative cells of the tumor were evident. Inflammatory reactions were also observed. In $\sim 40 \%$ of examined tumors, solid spindle cell areas and necrosis were more evident (Figure 2a, T1 and T2, and data not shown). Immunohistochemical analysis revealed high levels of estrogen receptor (ER) $\alpha$ in more than $90 \%$ of epithelial cells and focal progesterone receptor (PR) staining in neoplastic epithelial cells of all the tumor sections, while no HER2 staining was observed (Figure $2 \mathrm{a}$ and data not shown). Mammary tumor cells also exhibited less than $14 \%$ nuclei positive for the proliferation marker Ki-67, a feature that can segregate the luminal A subtype (Figure 2a and data not shown). Importantly, the profile of cytokeratin (CK) expression in the tumor cells reflected a luminal cell phenotype, as revealed by a strong positivity for the luminal cell markers CK8/18 and no expression of the basal markers CK5, CK6 and CK14 (Figure 2a and data not shown). ER $\alpha$ and PR protein levels in tumors were confirmed by immunoblotting (Figure 2b). Moreover, the levels of aromatase, the enzyme responsible for enhanced 'in situ' estrogen production from circulating androgens, were higher in mammary tumors than in normal mammary gland (Figure $2 b$ ).

To further characterize MG-Ki-Ras ${ }^{(\mathrm{G} 12 \mathrm{~V})}$ mice, we analysed in 6 additional tumors the transcript levels of genes differentially expressed in human breast tumor subtypes ${ }^{1,2,21,22}$. All expressed high levels of key markers of human luminal breast tumors (e.g. Gata3, Krt8, Krt18, Xbpl and Esrl), as 
well as estrogen-regulated genes (e.g. Tff1, Slc39a6, Rerg), but not of human basal-like tumors (e.g. Krt14, Krt17, Cryab) or of HER2-enriched tumors (Erbb2) (Figure 3).

Therefore, MG-Ki-Ras ${ }^{(\mathrm{G} 12 \mathrm{~V})}$ mice develop luminal A-like ER-positive mammary tumors at full penetrance within a couple of months.

\section{Establishment and characterization of MG-Ki-Ras ${ }^{(\mathrm{G} 12 \mathrm{~V})}$ mouse mammary tumor cell lines.}

Two cell lines, termed mMTC1 and mMTC2, were successfully generated from mammary tumors from two MG-Ki-Ras ${ }^{(\mathrm{G} 12 \mathrm{~V})}$ mice. Phase-contrast microscopy revealed a rounded epithelial morphology for mMTC1 cells and a spindle-like one for mMTC2 cells (Figure 4a). Both cell lines expressed Ki-Ras, ER $\alpha, \mathrm{PR}$ and aromatase (Figure 4b), and were pan-cytokeratin-positive and vimentin-negative, indicative of an epithelial origin (Figure 4c). Moreover, mMTC1 and mMTC2 cells proliferated more than human Luminal A-type breast cancer cell line MCF-7 (doubling time of 24 h versus 39 h, Figure 4d).

To further characterize these cell lines, their hormone sensitivity was determined. The effect of estrogens on their proliferation was evaluated using anchorage-dependent and -independent growth assays. Treatment with $17 \beta$-estradiol $\left(\mathrm{E}_{2}\right)$ increased cell proliferation, and the pure antiestrogen ICI 182780 antagonized this effect (Figure 5a and b). Moreover, in agreement with the expression of the aromatase enzyme, the growth of mMTC1 and mMTC 2 cells was enhanced by the aromatase substrate androstenedione (AD), and $\mathrm{AD}$-stimulated growth was blunted by the nonsteroidal aromatase inhibitor anastrozole (Figure 5c). Moreover, the levels of proteins encoded by classical estrogen-responsive target genes such as pS2 and cyclin D1 were increased in estrogen-treated cells (Figure 5d). Time course-response studies were conducted to analyze phosphorylation of ER $\alpha$ and downstream effectors using immunoblot analysis. In agreement with previous findings reported in human ER $\alpha$-positive breast cancer, ${ }^{23-25}$ basal levels of phosphorylated ER $\alpha$ at serine 118 , Akt at serine 473 and MAPK at threonine 202/tyrosine 204 were increased upon short exposure to estrogen (Figure 5e).

To investigate whether both cell lines grow as xenograft tumors, we injected mMTC1 and mMTC2 cells into the mammary fat pad of ovariectomized nude mice $(n=8)$ after implantation of $E_{2}$ pellets. Tumors were detected at day 7, with a 100\% incidence and grew rapidly (Figure 6a), demonstrating that mMTC1 and mMTC2 cells are tumorigenic. Interestingly, tumors generated from both cell lines were histologically similar to the original tumors, as revealed by H\&E staining (Figure 6b), and expressed ER $\alpha$, PR and aromatase (Figure 6c).

Moreover, treatment of mMTC2 orthotopic xenografted mice with ICI 182780 decreased tumor growth (Figure 6d). Four days after the last treatment, tumor size and weight were $>30 \%$ lower in 
ICI 182780-treated than in vehicle-treated mice (Figure 6e and f). Note that ICI 182780 administration was well tolerated, as body weight, food and water consumption, locomotor functions, as well as mean weights and histologic features of the major organs (liver, spleen, and kidney) were similar in treated- and untreated mice (data not shown).

Taken together, these results show that re-derivation of tumors as primary cell lines represents an accessible, easily usable set of biological models of high translational relevance. 


\section{Discussion}

Genetically engineered mouse models (GEMMs) are valuable tools to investigate the pathogenesis and progression of cancers, and to evaluate anticancer agents targeted to various aspects of carcinogenesis in vivo. Although a number of cancer GEMMs have been developed, an individual model may recapitulate only some aspects of this complex disease. In particular, in breast cancer these features include distinct histopathological subtypes, genetic and genomic variability, and diverse prognostic outcomes. In our transgenic mouse model, the expression of $\mathrm{Ki}^{-\mathrm{Ras}}{ }^{(\mathrm{G} 12 \mathrm{~V})}$ in the mammary gland induced by Cre-mediated recombination during lactation, leads to the development of invasive ductal estrogen receptor (ER) $\alpha$-positive adenocarcinoma.

It is well established that activating mutations in Ras family members promote both proliferation and tumorigenesis in mammalian cells, and occur in approximately $30 \%$ of all human cancers. ${ }^{10}$ Although Ki-Ras is mutated in a minor fraction of breast tumors [ 7\% in cancer tissues and $\sim 13 \%$ in cell lines ${ }^{26,27}$, Ras levels are higher in about $70 \%$ of primary breast cancers compared to normal tissue. ${ }^{28}$ Moreover, perturbation of Ras signaling, due to genetic alterations of upstream kinases, such as HER2/neu and EGFR, has been shown to contribute to oncogenesis, ${ }^{29-31}$ since these kinases are frequently overexpressed in human breast tumors and cell lines. ${ }^{32}$ In addition, Ras driven by WAP and MMTV promoters in transgenic mice is sufficient to induce hyperplasia, adenocarcinoma, and metastatic mammary tumors. ${ }^{33-35}$ In a particular strain of genetically modified animals, histopathological analysis of mutant Ki-Ras ${ }^{(\mathrm{G} 12 \mathrm{D})}$-induced mammary carcinomas revealed four coexistent types of invasive carcinomas at variable proportions, including adenocarcinomas (ER+/PR+ Dunn-type A/B tumors) that resemble luminal-type cancers, as well as pale, squamous and spindle cell carcinomas that correspond to basal-like breast carcinomas ${ }^{19}$.

Immunophenotyping of MG-Ki-Ras ${ }^{(\mathrm{G} 12 \mathrm{~V})}$ mice using a panel of clinically relevant markers showed that the adenocarcinomas are positive for ER $\alpha$ and PR, as well as for the luminal cell markers, cytokeratins 8/18, and negative for HER2. In addition, the tumors express transcripts selectively found in human luminal breast cancer (e.g. Gata3, Ckrt8, Xbpl and ER $\alpha$ ), as well as estrogenregulated genes (e.g. Tff1, Slc39a6, Rerg). Finally, Ki67 expression was low in these tumors. Thus, the mammary tumors of MG-Ki-Ras ${ }^{(\mathrm{G} 12 \mathrm{~V})}$ exhibit the key characteristics of ER/PR-positive, luminal A-like subtype of human breast cancer. The selective induction of luminal mammary tumors in MG-Ki-Ras ${ }^{(\mathrm{G} 12 \mathrm{~V})}$ mice might result from the intersection of the induction of Cre-mediated DNA recombination resulting from BLG promoter-driven Cre expression during pregnancy and/or lactation, and subsequent MMTV-driven Ki-Ras ${ }^{(\mathrm{G} 12 \mathrm{~V})}$ expression.

Because most human breast cancers are ER-positive, breast cancer animal models expressing ER $\alpha$ represent an excellent tool to study carcinogenesis in vivo, and evaluate treatment efficacy. 
Susceptible rats exposed to carcinogenic chemicals, radiation or estrogenic hormones for prolonged periods show a high incidence of ER-positive lesions (85-90\%). However, rats mainly display fibroadenoma rather than mammary adenocarcinoma, while mice predominantly exhibit adenocarcinomas that are mostly hormone-independent. ${ }^{5,36}$ The few transgenic mouse models developing ER-positive mammary tumors were obtained by either overexpression of ER $\alpha$ in mammary epithelial cells, or by genetic aberrations of other molecules within the estrogen signaling pathway (i.e. cyclin D1, prolactin, PI3K, and STAT1), combined or not with pharmacologic treatments or exposure to chemical carcinogens. An additional model resulted from brother-sister mating of nude mice (reviewed in ${ }^{37}$ ). Nevertheless, these models exhibit a high variability in the age of cancer development (3-26 months), in tumor penetrance and in the frequency of ER-positive cancers.

Compared to the above reported engineered mice, our novel mouse model displays ER $\alpha$-positive adenocarcinoma at full penetrance within 3 to 9 months after $\mathrm{Ki}_{-} \mathrm{Ras}^{(\mathrm{G} 12 \mathrm{~V})}$ induction, providing new opportunities to study ER-positive mammary tumors. Interestingly, Ki-Ras ${ }^{(\mathrm{G} 12 \mathrm{~V})}$-induced adenocarcinomas express high levels of aromatase, a key enzyme in estrogen biosynthesis. Local estrogen production from aromatase, that may be activated by various membrane cell signalings, is an important mechanism of autocrine and paracrine growth stimulation in hormone-dependent breast cancers. ${ }^{38-41}$

Cell lines isolated from GEMM tumors present a unique opportunity to study the similarities and changes that arise in a tissue culture environment. Moreover, since the GEMM tumor from which any line is derived is readily accessible, these cells can be used as first-pass screening tools to select and study the function of various genes by manipulation and to evaluate specific treatment regimens. In the present study, we have successfully generated and characterized two mouse mammary tumors cell lines derived from Ki-Ras-induced mammary tumors, termed mMTC1 and mMTC2, enhancing the translational relevance of our present engineered mouse model. mMTC1 and mMTC2 cell lines show typical epithelial morphology and are highly concordant with the molecular features found in MG-Ki-Ras ${ }^{(\mathrm{G} 12 \mathrm{~V})}$ tumors (i.e. Ki-Ras, ER $\alpha$, PR and aromatase expression). Importantly, cell growth is enhanced by estrogens and blunted by the ER antagonist ICI 182780. Moreover, the expression of classical estrogen-responsive target genes (i.e. cyclin D1 and pS2) are stimulated by estrogens, and phosphorylation levels of ER $\alpha$ and of estrogen rapid downstream effectors (i.e. Akt and MAPK) were enhanced in mMTC1 and mMTC2 cells 5 minutes after estradiol treatment, and thus reproducing the phosphorylation events induced by short exposure of human ER $\alpha$-positive breast cancer cells to estradiol. ${ }^{24,25}$ In addition, consistently with the observed expression of the aromatase enzyme, the growth of mMTC1 and mMTC2 cells was 
enhanced by treatment with the aromatase substrate androstenedione and this induction was blunted by the nonsteroidal aromatase inhibitor anastrozole. When transplanted into ovariectomized female nude mice implanted with estradiol pellets, these cell lines generated tumors, which responded to the antiestrogen ICI 182780. Importantly, palpable tumors were detected within one week, in contrast to available human ER-positive breast cancer cell lines (e.g. MCF-7) which require about one month. ${ }^{42}$

In conclusion, MG-Ki-Ras ${ }^{(\mathrm{G} 12 \mathrm{~V})}$ mice develop within a couple of months at full penetrance mammary tumors that recapitulate the most common human breast cancer subtype, classified as ductal ER-positive invasive adenocarcinoma. Together with the derived primary cancer cell line, they represent valuable preclinical platforms to investigate the biology of estrogen-dependent mammary tumors and to test various therapeutic agents.

\section{Materials and Methods}

\section{Generation of transgenic mice.}

The MMTV-LoxP-EGFP-LoxP-Ki-Ras ${ }^{(\mathrm{G} 12 \mathrm{~V})}$ plasmid was constructed as following: a 1200bp bluntended Not1 fragment, containing a LoxP flanked Enhanced Green Fluorescent Protein stop cassette was inserted into the Sma I site of pGS, ${ }^{43}$ resulting in pGS-LoxP-EGFP-LoxP. The $1800 \mathrm{bp}$ BgIII fragment containing the rabbit $\beta$-intron II and the LoxP flanked Enhanced Green Fluorescent Protein stop cassette isolated from pGS-LoxP-EGFP-LoxP were cloned into BgIII of the MMTVKi-ras ${ }^{(\mathrm{G} 12 \mathrm{~V})}$ (provided by Merck Research Laboratories, Pennsylvania), encoding the human KiRasB cDNA with a nucleotide change from GGT (encoding a glycine, G) to GTT (encoding a valine, V) at codon 12 under the control of the MMTV-LTR promoter, resulting in pMMTV-LoxPEGFP-LoxP-Ki-Ras ${ }^{(\mathrm{G} 12 \mathrm{~V})}$. A $4.9 \mathrm{~kb}$ HindIII DNA fragment was purified from pMMTV-LoxPEGFP-LoxP-Ki-Ras ${ }^{(\mathrm{G} 12 \mathrm{~V})}$ and injected into (C57BL/6/SJL) F1 zygotes, as described ${ }^{44,45}$, to generate MMTV-LoxP-EGFP-LoxP-Ki-Ras ${ }^{(\mathrm{G} 12 \mathrm{~V})}$ founder mice, that were backcrossed on C57BL/6 mice for more than 8 generations. Breeding and maintenance of mice were performed in the accredited IGBMC/ICS animal house (A67-218-37 notification of 16/10/2013), in compliance with French and EU regulations on the use of laboratory animals for research, under the supervision of D. M. who holds animal experimentation authorizations from the French Ministry of agriculture and Fisheries ( $\mathrm{N}^{\circ}$ 67-209 and C 67-2018-37). All experiments of genetically engineered mice were approved by the Ethical committee Com'Eth (Comité d'Ethique pour l'Expérimentation Animale, Strasbourg, France).

\section{Identification of the BLG-Cre and MMTV-LoxP-EGFP-LoxP-Ki-ras ${ }^{(G 12 V}$ alleles.}


BLG-Cre mice ${ }^{20}$ were backcrossed on C57BL/6 mice for more than 8 generations. DNA for PCR analysis was isolated from mouse tissues by proteinase $\mathrm{K}$ digestion and phenol extraction. Mice were genotyped by PCR amplification of tail DNA using the primers 5'ATTTGCCTGCATTACCGGTC-3' and 5'-ATCAACGTTTTCTTTTCGGA-3' for the BLG-Cre transgene and P3 5'-CAGCCGCTACCCCGACCACA-3' and P4 5'CACCTTGATGCCGTTCTTCT-3' for the MMTV-LoxP-EGFP-LoxP-Ki-Ras ${ }^{(\mathrm{G} 12 \mathrm{~V})}{ }^{\text {transgene. The }}$ primers used to amplify the various $\mathrm{Ki}_{-} \mathrm{Ras}^{(\mathrm{G} 12 \mathrm{~V})}$ alleles in tissues were P1 5'ACCATGTTCATGCCTTCT-3', P2 5'-GCTCCAACCACCACAAGTTT-3', P3 and P4 (see Figure 1a). Primers for the internal control (IC) were: 5'-TTACGTCCATCGTGGACAGC-3' and 5'TGGGCTGGGTGTTAGCCTTA-3'.

\section{Analysis of tissue morphology.}

The fourth inguinal mammary gland pair was dissected from each mouse. One gland was analyzed by whole mount and the other was paraformaldehyde-fixed and paraffin-embedded. Whole mounts were performed by spreading the gland on a glass slide and incubation (3h) with Carnoy's fixative (60\% ethanol, 30\% chloroform, 10\% glacial acetic acid). The glands were then incubated with a graded series of $70 \%, 50 \%$ and $25 \%$ ethanol (15min each), followed by $5 \mathrm{~min}$ in water and stained with carmine alum overnight. Finally, the glands were washed in $70 \%$, 90\% and 100\% ethanol (15min each), cleared by submersion in xylene (30min), and then mounted with Permount (Fisher Scientific).

\section{Total RNA extraction and $q R T-P C R$ analysis.}

TRIzol reagent was used to obtain total RNA and SYBR Green Universal PCR Master Mix (BioRad) to perform real-time RT-PCR. Primers used are indicated in Table 1. Samples were normalized on 18S (TaqMan rRNA Reagent kit, Applied Biosystems) or 36B4 mRNA content. Relative gene expression levels were calculated as reported. ${ }^{46}$

\section{Histological analysis.}

Analysis of tissue sections was performed using tissue fixed in $4 \%$ paraformaldehyde for $24 \mathrm{~h}$, dehydrated, and embedded in paraffin. Tissue blocks were sectioned at $4 \mu \mathrm{m}$ and were stained using Mayer's hematoxylin and eosin to facilitate histology and morphology evaluation.

\section{Immunohistochemistry.}


For immunohistochemistry, antigen retrieval was performed on $5 \mu \mathrm{m}$ paraffin sections using a Decloaking Chamber (Biocare Medical) with citrate buffer at $\mathrm{pH} 6.0$ at $125{ }^{\circ} \mathrm{C}$, and 15 psi pressure, for $45 \mathrm{~min}$. Incubations with primary antibodies were performed at room temperature overnight in a humidified chamber. Primary antibodies used were anti-ER $\alpha$ (SC-542, Santa Cruz Biotechnology), anti-PR (A0098, Dako), anti-Her2 (Lab Vision, RB-103-PIABX), anti-Ki67 (Lab Vision, RB-1510PO), anti CK5 (Abcam, ab24647), anti-CK6 (Abcam, ab24646-50), anti-CK14 (Lab Vision, RB9020-P1), and anti-CK8/18 (Fitzgerald, 20R-CP004). Normal goat serum was used as blocking agent. Biotinylated goat anti-rabbit (1:1000) was used as the secondary antibody and revealed with a Vectastain ABC Kit Elite and a Peroxidase Substrate Kit DAB (Vector Labs). Tissues known to express each assessed antigen were used as positive controls. Antibody deletion controls were used for every assessed antigen to confirm specific staining. All stained slides were scanned and digitized using the Aperio ScanScope AT2 to capture digital whole slide images (WSI), stored in the CGP Spectrum database and analysed using Aperio Immage Scope. Ki-67 values score were acquired as the percentage of positively nuclear immunostained malignant cells among the total number of malignant cells assessed. A Ki-67 cut-off point of $14 \%$ was defined according to the experience of different pathologists, as well as national and international recommendations at present.

\section{Isolation of primary cells from mouse mammary tumors.}

Mammary tumor tissue from 24 week-old MG-Ki-Ras ${ }^{(\mathrm{G} 12 \mathrm{~V})}$ mice was isolated and processed in a sterile manner. Tissues (100-200 mg) were washed with PBS, incubated in PBS with penicillin/streptomycin (Life Technologies) for $1 \mathrm{~h}$ at RT, cut into small pieces and digested with 10X collagenase/hyaluronidase solution (StemCell Technologies) to a final concentration of $0.5 \mathrm{X}$ in DMEM for $16 \mathrm{~h}$ at $37^{\circ} \mathrm{C}$ with orbital shaking at $75 \mathrm{rpm}$. Following digestion, they were centrifuged at $500 \mathrm{~g}$ for $5 \mathrm{~min}$ at RT. The supernatant was discarded and the pellet was washed with PBS and was further digested with $0.05 \%$ Trypsin (Life Technologies) in $1 \times \mathrm{PBS}$, for $5 \mathrm{~min}$ at $37^{\circ} \mathrm{C}$. For trypsin inactivation, $5 \mathrm{ml}$ of DMEM containing 5\% Fetal Bovine Serum (FBS) was added, the cells were resuspended and centrifuged at $500 \mathrm{~g}$ for $5 \mathrm{~min}$ at RT. The pellet was washed and resuspended with PBS $+1 \%$ BSA. Subsequently, epithelial cells from two different tumors, termed as mMTC1 and mMTC2, were selected by magnetic cell separation (Miltenyi) following manufacturer's protocol. mMTC1 and mMTC2 cells were cultured in Dulbecco's modified Eagle's medium (DMEM) supplemented with $10 \% \mathrm{FBS}$, and $1 \mathrm{mg} / \mathrm{ml}$ penicillin-streptomycin at $37^{\circ} \mathrm{C}$ with $5 \% \mathrm{CO} 2$ air. Tumor cell lines were obtained after at least 10 passages and then were used for subsequent experiments. 


\section{Cell culture.}

Human breast cancer MCF-7 cells, acquired in 2015 from American Type Culture Collection, were authenticated, stored following the instructions of the supplier, and used within 4 months after thawing frozen aliquots. MCF-7 cells were cultured in DMEM medium containing $10 \% \mathrm{FBS}, 1 \%$ L-glutamine, 1\% Eagle's nonessential amino acids, and $1 \mathrm{mg} / \mathrm{ml}$ penicillin-streptomycin. Isolation of human cancer associated fibroblasts (CAFs) from primary breast tumors of patients who signed informed consent was previously reported. ${ }^{47}$ CAFs were cultured in RPMI-1640 medium supplemented with $15 \% \mathrm{FBS}$ and $1 \mathrm{mg} / \mathrm{ml}$ penicillin-streptomycin. Negativity for mycoplasma was evaluated every 4 months (MycoAlert, Lonza).

\section{Immunoblotting.}

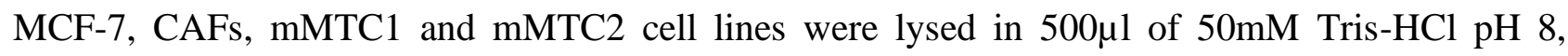
$150 \mathrm{mM} \mathrm{NaCl}, 1 \%$ Nonidet P-40, $0.5 \%$ sodium deoxycholate, $2 \mathrm{mM}$ sodium fluoride, $2 \mathrm{mM}$ EDTA, $0.1 \%$ SDS, containing a mixture of protease inhibitors (aprotinin, phenylmethylsulfonyl fluoride, and sodium orthovanadate) for protein extraction. Tissues were homogenized in lysis buffer supplemented with $10 \%$ glycerol. Immunoblotting was performed as described, ${ }^{48}$ using the following antibodies: K-Ras (sc-30, Santa Cruz Biotechnology, 1:500), ER $\alpha$ (sc-542, Santa Cruz Biotechnology, 1:1000), PR (sc-538, Santa Cruz Biotechnology, 1:500), pan-Cytokeratin (sc-8018, Santa Cruz Biotechnology, 1:1000), Vimentin (sc-6260, Santa Cruz Biotechnology, 1:1000), phospho-Akt1/2/3 ${ }^{\text {Ser473 }}$ (sc-7985, Santa Cruz Biotechnology, 1:1000), Akt1/2/3 (sc-8312, Santa

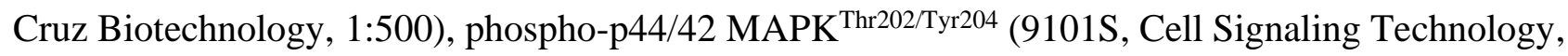
1:1000), p44/42 MAPK (9102, Cell Signaling Technology, 1:500), phospho-ERa ${ }^{\text {Ser118 }}$ (2515S, Cell Signaling Technology, 1:500), Aromatase (mca2077s, Serotec, 1:2000) and $\beta$-Tubulin (sc-5286, Santa Cruz Biotechnology, 1:10000). Scion Image laser densitometry scanning program (Scion Corporation, MD, USA) was used to measure protein band intensities for the biological replicates. One representative image from three separate experiments was shown.

\section{Growth kinetics assay.}

Cells $\left(1 \times 10^{4}\right.$ in $1 \mathrm{ml}$ of DMEM medium containing $1 \%$ FBS $)$ were seeded in twelve-well plates and grown for 1 to 6 days. The growth rate was determined by counting the number of cells using a countess automated cell counter (Life Technology) in triplicate. The formula used to calculate cell population doubling time (Td) during the phase of exponential growth was the following: $\mathrm{Td}=0.693$ 
$\mathrm{t} / \mathrm{ln}(\mathrm{Nt} / \mathrm{N} 0)$, $\mathrm{t}$ represents time difference (hours), $\mathrm{Nt}$ and $\mathrm{N} 0$ represent the number of cells at time $\mathrm{t}$ and at initial time, respectively. ${ }^{49}$

\section{Cell proliferation assays.}

Trypan blue cell count assays. Cells $\left(3 \times 10^{4}\right.$ cells $\left./ \mathrm{ml}\right)$ were plated in twelve-well plates in medium supplemented with $10 \%$ FBS. After $24 \mathrm{~h}$ they were grown in phenol red-free medium containing $2 \%$ charcoal-stripped FBS for 2 days and treated with 17ß-estradiol (10nM, Sigma) and/or ICI 182780 $(1 \mu \mathrm{M}$, Tocris Bioscience), and 4-androstene-3,17-dione (100nM, Sigma) and/or Anastrozole (1 $\mu \mathrm{M}$, Sigma). After $24 \mathrm{~h}$ and $48 \mathrm{~h}$ of treatment, cell numbers were estimated in trypsinized suspensions using a countess automated cell counter.

Anchorage-independent soft agar growth assays. Growth assays were conducted as reported. ${ }^{50}$

Data represent 3 independent experiments performed in triplicate.

\section{Immunofluorescence.}

Cells were fixed with $4 \%$ paraformaldehyde, permeabilized with PBS+0.2\% Triton X-100 followed by blocking with $5 \%$ bovine serum albumin, and incubated with anti-Cyclin D1 or pS2 antibodies (Santa Cruz Biotechnology) and with fluorescein isothiocyanate-conjugated secondary antibody (Sigma). Negative control: IgG primary antibody. 4',6-Diamidino-2-phenylindole (DAPI; Sigma) staining was used to detect nuclei. Fluorescence was photographed with OLYMPUS-BX51 microscope, 100x objective.

\section{Tumor xenografts.}

Eight week-old ovariectomized athymic nude female mice were injected orthotopically with mMTC1 and mMTC2 cells $\left(3 \times 10^{6}\right)$. Animals were supplemented with $17 \beta$-estradiol pellets $(0.72 \mathrm{mg}$ per pellet, 90-day release; Innovative Research of America, Sarasota, FL) 24 hours before tumor cell inoculation. In another set of experiments, when the mean tumor size reached $0.2 \mathrm{~cm}^{3}$ (day 0 ), mice were randomized into two groups and treated with vehicle or ICI 182760 (5mg/mouse) administered weekly via s.c. injection. Tumor development was followed in a blind fashion and volumes assessed as described.$^{50}$ Calculation of sample size was done with the resource equation method, based on measurement of "E" value. ${ }^{51}$ All animal studies were carried out according to the Guidelines for the Care and Use of Laboratory Animals and were approved by the Animal Care Committee of University of Calabria, Italy.

\section{Statistical analysis.}


Each datum point denotes the mean \pm S.E.M. (Standard Error of Mean) of three separate experiments. Data were examined with Student's t test using the GraphPad Prism 4 software program. $\mathrm{P}<0.05$ was considered to be statistically significant.

\section{Supplementary Information accompanies the paper on the Oncogene website (http://www.nature.com/onc)}

Conflict of interest: The authors declare no conflict of interest.

Acknowledgements: We are grateful to Dr. Watson and Dr. Whitelaw for BLG-Cre mice, to Merck Research Laboratories for the MMTV-Ki-Ras ${ }^{(\mathrm{G} 12 \mathrm{~V})}$ plasmid, and to Catherine Tomasetto and Fabien Alpy for helpful discussions. We thank Neil E. Hubbard and Judith Walls (Center for Comparative Medicine, University of California, Davis, California, USA), the staff of the mouse and genetic engineering facilities from ICS and IGBMC, and Elise Grelet for their excellent assistance. 


\section{References}

1. Perou CM, Sorlie T, Eisen MB, van de Rijn M, Jeffrey SS, Rees CA, et al. Molecular portraits of human breast tumours. Nature 2000; 406: 747-752.

2. Sorlie T, Perou CM, Tibshirani R, Aas T, Geisler S, Johnsen H, et al. Gene expression patterns of breast carcinomas distinguish tumor subclasses with clinical implications. Proc Natl Acad Sci USA 2001; 98: 10869-10874.

3. Stewart TA, Pattengale PK, Leder P. Spontaneous mammary adenocarcinomas in transgenic mice that carry and express mtv/myc fusion genes. Cell 1984; 38: 627-637.

4. Andrechek ER, Hardy WR, Siegel PM, Rudnicki MA, Cardiff RD, Muller WJ. Amplification of the neu/erbb-2 oncogene in a mouse model of mammary tumorigenesis. Proc Natl Acad Sci USA 2000; 97: 3444-3449.

5. Cardiff RD, Anver MR, Gusterson BA, Hennighausen L, Jensen RA, Merino MJ, et al. The mammary pathology of genetically engineered mice: The consensus report and recommendations from the annapolis meeting. Oncogene 2000; 19: 968-988.

6. Green JE, Shibata MA, Yoshidome K, Liu ML, Jorcyk C, Anver MR, et al. The c3(1)/sv40 t-antigen transgenic mouse model of mammary cancer: Ductal epithelial cell targeting with multistage progression to carcinoma. Oncogene 2000; 19: 1020-1027.

7. Sandgren EP, Schroeder JA, Qui TH, Palmiter RD, Brinster RL, Lee DC. Inhibition of mammary gland involution is associated with transforming growth factor alpha but not cmyc-induced tumorigenesis in transgenic mice. Cancer Res 1995; 55: 3915-3927.

8. Schoenenberger CA, Andres AC, Groner B, van der Valk M, LeMeur M, Gerlinger P. Targeted c-myc gene expression in mammary glands of transgenic mice induces mammary tumours with constitutive milk protein gene transcription. EMBO J 1988; 7: 169-175. 
9. Sinn E, Muller W, Pattengale P, Tepler I, Wallace R, Leder P. Coexpression of mmtv/v-haras and mmtv/c-myc genes in transgenic mice: Synergistic action of oncogenes in vivo. Cell 1987; 49: 465-475.

10. Schubbert S, Shannon K, Bollag G. Hyperactive ras in developmental disorders and cancer. Nat Rev Cancer 2007; 7: 295-308.

11. Koera K, Nakamura K, Nakao K, Miyoshi J, Toyoshima K, Hatta T, et al. K-ras is essential for the development of the mouse embryo. Oncogene 1997; 15: 1151-1159.

12. Johnson L, Greenbaum D, Cichowski K, Mercer K, Murphy E, Schmitt E, et al. K-ras is an essential gene in the mouse with partial functional overlap with n-ras. Genes Dev 1997; 11: 2468-2481.

13. Esteban LM, Vicario-Abejon C, Fernandez-Salguero P, Fernandez-Medarde A, Swaminathan N, Yienger $\mathrm{K}$, et al. Targeted genomic disruption of h-ras and n-ras, individually or in combination, reveals the dispensability of both loci for mouse growth and development. Mol Cell Biol 2001; 21: 1444-1452.

14. O'Hagan RC, Heyer J. Kras mouse models: Modeling cancer harboring kras mutations. Genes Cancer 2011; 2: 335-343.

15. Omer CA, Chen Z, Diehl RE, Conner MW, Chen HY, Trumbauer ME, et al. Mouse mammary tumor virus-ki-rasb transgenic mice develop mammary carcinomas that can be growth-inhibited by a farnesyl:Protein transferase inhibitor. Cancer Res 2000; 60: 26802688.

16. Gu H, Marth JD, Orban PC, Mossmann H, Rajewsky K. Deletion of a DNA polymerase beta gene segment in t cells using cell type-specific gene targeting. Science 1994; 265: 103-106. 
17. Lakso M, Sauer B, Mosinger B, Jr., Lee EJ, Manning RW, Yu SH, et al. Targeted oncogene activation by site-specific recombination in transgenic mice. Proc Natl Acad Sci USA 1992; 89: 6232-6236.

18. Metzger D, Chambon P. Site- and time-specific gene targeting in the mouse. Methods 2001; 24: 71-80.

19. Klinakis A, Szabolcs M, Chen G, Xuan S, Hibshoosh H, Efstratiadis A. Igf1r as a therapeutic target in a mouse model of basal-like breast cancer. Proc Natl Acad Sci USA 2009; 106: 2359-2364.

20. Selbert S, Bentley DJ, Melton DW, Rannie D, Lourenco P, Watson CJ, et al. Efficient blgcre mediated gene deletion in the mammary gland. Transgenic Res 1998; 7: 387-396.

21. Herschkowitz JI, Simin K, Weigman VJ, Mikaelian I, Usary J, Hu Z, et al. Identification of conserved gene expression features between murine mammary carcinoma models and human breast tumors. Genome Biol 2007; 8: R76.

22. Habashy HO, Powe DG, Abdel-Fatah TM, Gee JM, Nicholson RI, Green AR, et al. A review of the biological and clinical characteristics of luminal-like oestrogen receptorpositive breast cancer. Histopathology 2012; 60: 854-863.

23. Barone I, Cui Y, Herynk MH, Corona-Rodriguez A, Giordano C, Selever J, et al. Expression of the K303R estrogen receptor-alpha breast cancer mutation induces resistance to an aromatase inhibitor via addiction to the pi3k/akt kinase pathway. Cancer Res 2009; 69 : 4724-4732.

24. McGlynn LM, Tovey S, Bartlett JM, Doughty J, Cooke TG, Edwards J. Interactions between map kinase and oestrogen receptor in human breast cancer. Eur J Cancer 2013; 49: 1176-1186. 
25. Chen M, Cui YK, Huang WH, Man K, Zhang GJ. Phosphorylation of estrogen receptor alpha at serine 118 is correlated with breast cancer resistance to tamoxifen. Oncol Lett 2013; 6: $118-124$.

26. Hollestelle A, Elstrodt F, Nagel JH, Kallemeijn WW, Schutte M. Phosphatidylinositol-3-oh kinase or ras pathway mutations in human breast cancer cell lines. Mol Cancer Res 2007; 5: 195-201.

27. Malaney S, Daly RJ. The ras signaling pathway in mammary tumorigenesis and metastasis. J Mammary Gland Biol Neoplasia 2001; 6: 101-113.

28. Dati C, Muraca R, Tazartes O, Antoniotti S, Perroteau I, Giai M, et al. C-erbb-2 and ras expression levels in breast cancer are correlated and show a co-operative association with unfavorable clinical outcome. Int J Cancer 1991; 47: 833-838.

29. Loboda A, Nebozhyn M, Klinghoffer R, Frazier J, Chastain M, Arthur W, et al. A gene expression signature of ras pathway dependence predicts response to pi3k and ras pathway inhibitors and expands the population of ras pathway activated tumors. BMC Med Genomics 2010; 3: 26.

30. von Lintig FC, Dreilinger AD, Varki NM, Wallace AM, Casteel DE, Boss GR. Ras activation in human breast cancer. Breast Cancer Res Treat 2000; 62: 51-62.

31. Eckert LB, Repasky GA, Ulku AS, McFall A, Zhou H, Sartor CI, et al. Involvement of ras activation in human breast cancer cell signaling, invasion, and anoikis. Cancer Res 2004; 64: 4585-4592.

32. Howe LR, Brown PH. Targeting the her/egfr/erbb family to prevent breast cancer. Cancer Prev Res (Phila) 2011; 4: 1149-1157. 
33. Shen Q, Brown PH. Transgenic mouse models for the prevention of breast cancer. Mutat Res 2005; 576: 93-110.

34. Reddy HK, Graña X, Dhanasekaran DN, Litvin J, Reddy EP. Requirement of Cdk4 for vHa-ras-Induced Breast Tumorigenesis and Activation of the v-ras-Induced Senescence Program by the R24C Mutation. Genes Cancer 2010; 1: 69-80.

35. Podsypanina K, Politi K, Beverly LJ, Varmus HE. Oncogene cooperation in tumor maintenance and tumor recurrence in mouse mammary tumors induced by Myc and mutant Kras. Proc Natl Acad Sci USA 2008; 105: 5242-5247.

36. Nandi S, Guzman RC, Yang J. Hormones and mammary carcinogenesis in mice, rats, and humans: A unifying hypothesis. Proc Natl Acad Sci USA 1995; 92: 3650-3657.

37. Dabydeen SA, Furth PA. Genetically engineered eralpha-positive breast cancer mouse models. Endocr Relat Cancer 2014; 21: R195-208.

38. Santen RJ, Brodie H, Simpson ER, Siiteri PK, Brodie A. History of aromatase: Saga of an important biological mediator and therapeutic target. Endocr Rev 2009; 30: 343-375.

39. Catalano S, Barone I, Marsico S, Bruno R, Ando S. Phosphorylation processes controlling aromatase activity in br east cancer: An update. Mini Rev Med Chem 2016; 16: 691-698.

40. Catalano S, Barone I, Giordano C, Rizza P, Qi H, Gu G, et al. Rapid estradiol/eralpha signaling enhances aromatase enzymatic activity in breast cancer cells. Mol Endocrinol 2009; 23: 1634-1645.

41. Barone I, Giordano C, Malivindi R, Lanzino M, Rizza P, Casaburi I, et al. Estrogens and PTP1B function in a novel pathway to regulate aromatase enzymatic activity in breast cancer cells. Endocrinology 2012; 153: 5157-5166. 
42. Mauro L, Catalano S, Bossi G, Pellegrino M, Barone I, Morales S, et al. Evidences that leptin up-regulates E-cadherin expression in breast cancer: effects on tumor growth and progression. Cancer Res 2007; 67: 3412-3421.

43. Indra AK, Warot X, Brocard J, Bornert JM, Xiao JH, Chambon P, et al. Temporallycontrolled site-specific mutagenesis in the basal layer of the epidermis: Comparison of the recombinase activity of the tamoxifen-inducible cre-er(t) and cre-er(t2) recombinases. Nucleic Acids Res 1999; 27: 4324-4327.

44. Feil R, Brocard J, Mascrez B, LeMeur M, Metzger D, Chambon P. Ligand-activated sitespecific recombination in mice. Proc Natl Acad Sci USA 1996; 93: 10887-10890.

45. Imai $\mathrm{T}$, Chambon $\mathrm{P}$, Metzger D. Inducible site-specific somatic mutagenesis in mouse hepatocytes. Genesis 2000; 26: 147-148.

46. Catalano S, Panza S, Malivindi R, Giordano C, Barone I, Bossi G, et al. Inhibition of leydig tumor growth by farnesoid $\mathrm{x}$ receptor activation: The in vitro and in vivo basis for a novel therapeutic strategy. Int J Cancer 2013; 132: 2237-2247.

47. Giordano C, Chemi F, Panza S, Barone I, Bonofiglio D, Lanzino M, Cordella A, Campana A, Hashim A, Rizza P, Leggio A, Győrffy B, Simões BM, Clarke RB, Weisz A, Catalano S, Andò S. Leptin as a mediator of tumor-stromal interactions promotes breast cancer stem cell activity. Oncotarget 2016; 7: 1262-1275.

48. Grande F, Barone I, Aiello F, Brancale A, Cancellieri M, Badolato M, et al. Identification of novel 2-(1h-indol-1-yl)-benzohydrazides cxcr4 ligands impairing breast cancer growth and motility. Future Med Chem 2016; 8: 93-106.

49. Singh AP, Moniaux N, Chauhan SC, Meza JL, Batra SK. Inhibition of muc4 expression suppresses pancreatic tumor cell growth and metastasis. Cancer Res 2004; 64: 622-630. 
50. Giordano C, Barone I, Vircillo V, Panza S, Malivindi R, Gelsomino L, et al. Activated fxr inhibits leptin signaling and counteracts tumor-promoting activities of cancer-associated fibroblasts in breast malignancy. Sci Rep -UK 2016; 6: 21782.

51. Charan J, Kantharia ND. How to calculate sample size in animal studies? J Pharmacol Pharmacother 2013; 4: 303-306. 


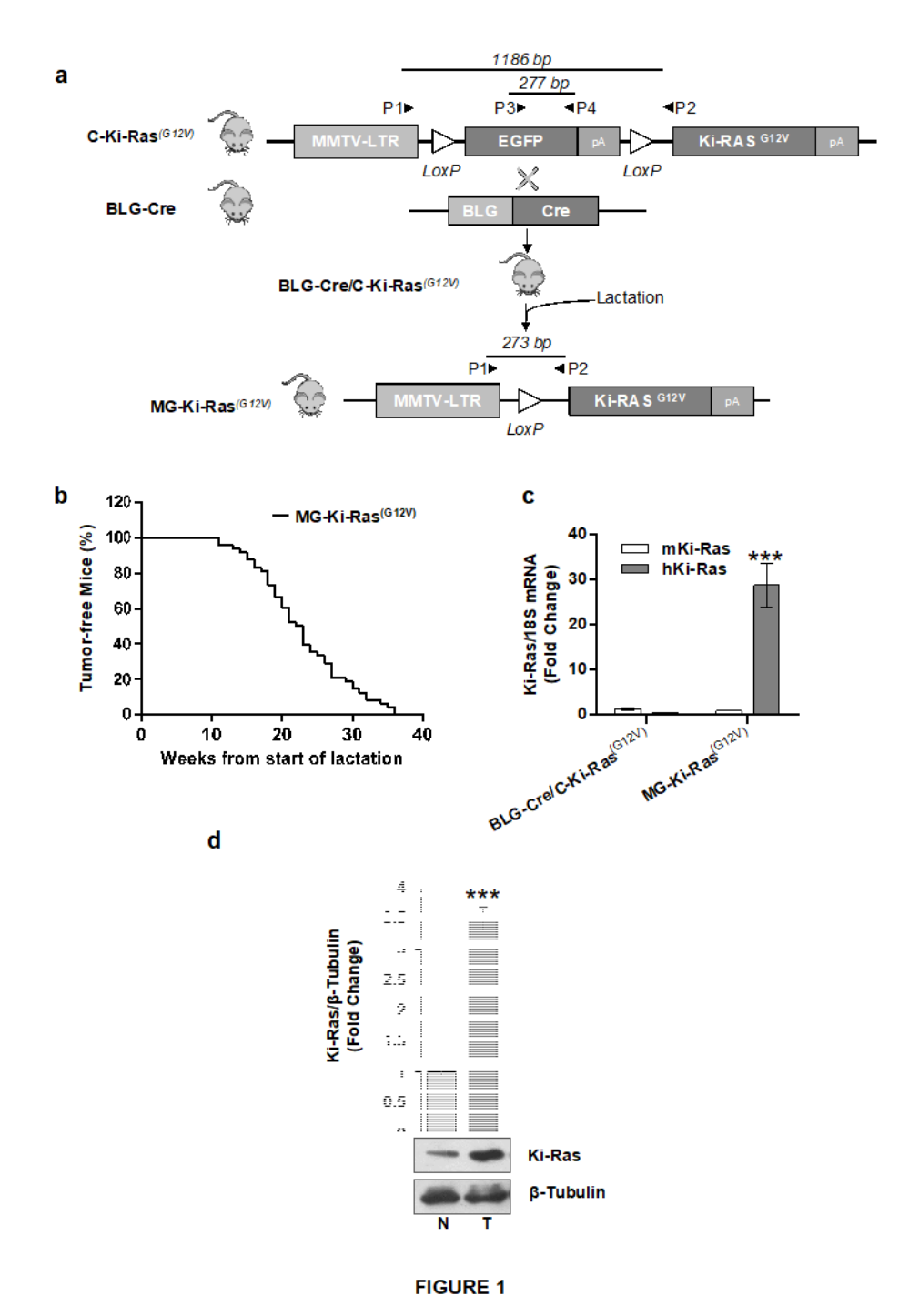

Figure 1: Generation of MG-Ki-Ras ${ }^{(\mathbf{G 1 2})}$ mice and characterization of Ki-Ras expression and mammary tumor development. (a) Schematic representation of the MMTV-LoxP-EGFP-LoxP$\mathrm{Ki}_{-\mathrm{Ras}}{ }^{(\mathrm{G} 12 \mathrm{~V})}$ transgene and breeding strategy to generate $\mathrm{MG}-\mathrm{Ki}-\mathrm{Ras}^{(\mathrm{G} 12 \mathrm{~V})}$ mice. Primers P1, P2, P3 and $\mathrm{P} 4$ used to amplify various alleles are indicated by arrows. (b) Kaplan-Meier tumor-free curves in MG-Ki-Ras ${ }^{(\mathrm{G} 12 \mathrm{~V})}$ mice $(\mathrm{n}=48)$. (c) $\mathrm{qRT}-\mathrm{PCR}$ of human and mouse Ki-Ras transcripts in mammary glands from virgin BLG-Cre/C-Ki-Ras ${ }^{(\mathrm{G} 12 \mathrm{~V})}$ and $\mathrm{MG}-\mathrm{Ki}-\mathrm{Ras}^{(\mathrm{G} 12 \mathrm{~V})}$ mice $(\mathrm{n}=4)$. Each sample was normalized to its $18 \mathrm{~S}$ RNA content. ***, $\mathrm{p}<0.0005$. The amplification primers for mouse and human Ki-ras showed no cross-amplification. Female BLG-Cre/C-Ki-Ras ${ }^{(G 12 V)}$ littermates were randomly selected to form cohorts of virgin BLG-Cre/C-Ki-Ras ${ }^{(\mathrm{G} 12 \mathrm{~V})}$ and $\mathrm{MG}-\mathrm{Ki}$ $\operatorname{Ras}^{(\mathrm{G} 12 \mathrm{~V})}$ mice (d) Representative results of immunoblotting for total Ki-Ras levels in neoplastic tissue $(\mathrm{T})$ and control mammary glands $(\mathrm{N})$. The histograms represent the mean \pm SEM of three separate experiments in which band intensities were evaluated in terms of optical density arbitrary units (OD) and expressed as fold change versus control mammary glands (N) normalized for $\beta$ Tubulin. $\mathrm{n}=4, * * *, \mathrm{p}<0.0005$. 
a

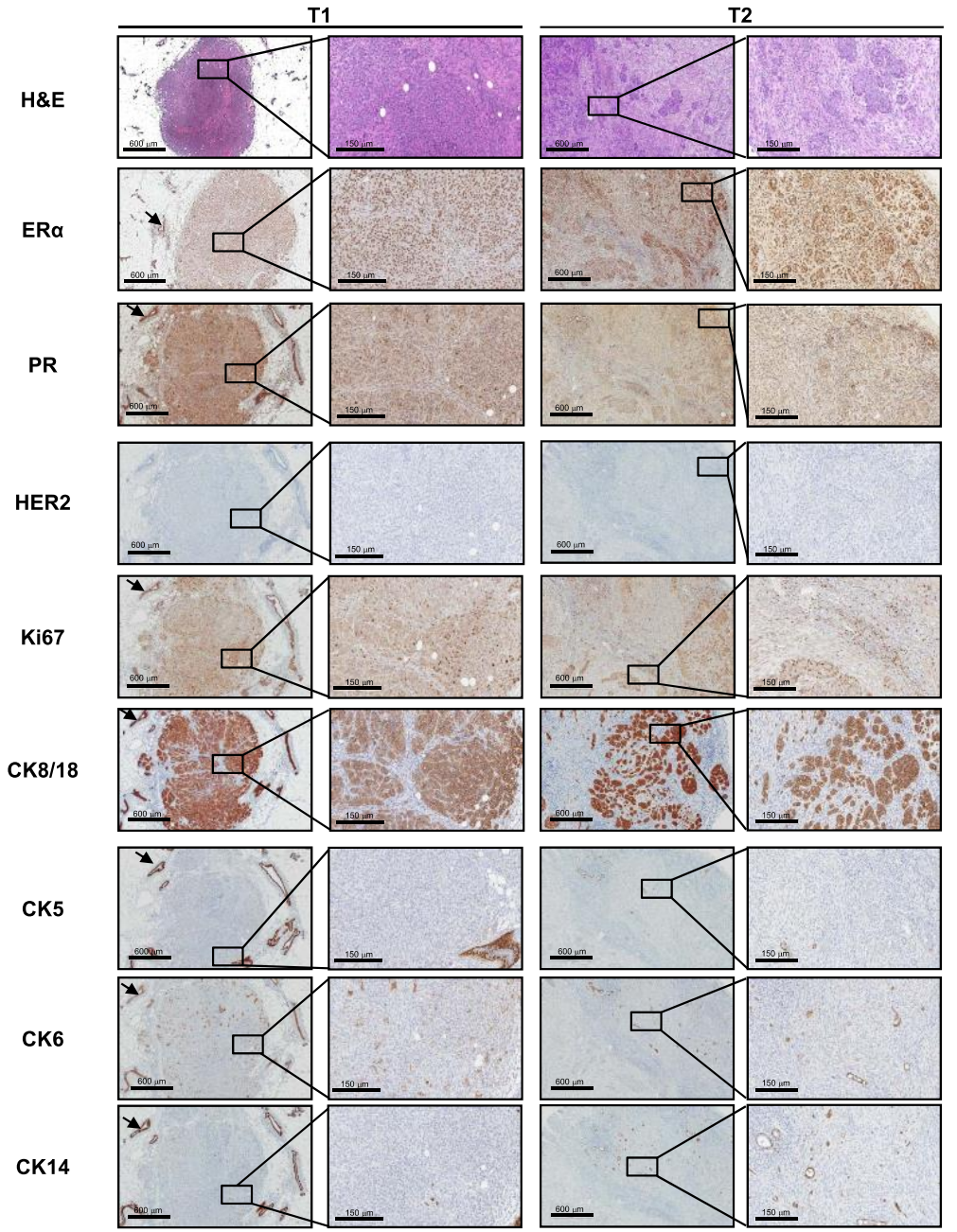

b
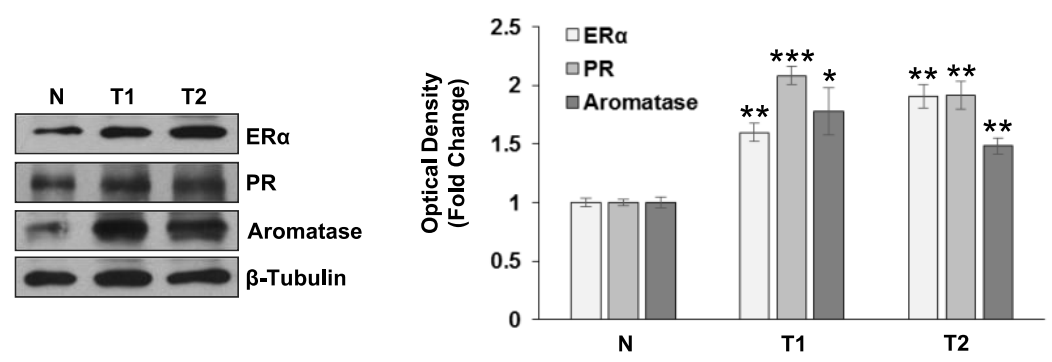

FIGURE 2

Figure 2: Histology and immunophenotyping of mammary carcinomas from MG-KiRas $^{(\mathbf{G 1 2 V})}$ mice. (a) Representative H\&E-stained sections and immunodetection of ER $\alpha$, PR, HER2, $\mathrm{Ki}-67$, and cytokeratins $(\mathrm{CK})$ in tumors of MG-Ki- Ras ${ }^{(\mathrm{G} 12 \mathrm{~V})}$ mice. Tumor $\mathrm{T} 1$ and $\mathrm{T} 2$ were taken 5 and 4 months after the start of lactation, respectively. Arrow, normal mammary glands, used as a control. (b) Immunoblotting of $\mathrm{T} 1$ and $\mathrm{T} 2$ protein extracts with antibodies directed against ER $\alpha, \mathrm{PR}$ and Aromatase. N, Normal mammary gland extracts. $\beta$-tubulin was used as a loading control. The histograms represent the mean \pm SEM of three separate experiments in which band intensities were evaluated in terms of optical density arbitrary units (OD) and expressed as fold change versus control mammary glands $(\mathrm{N})$ normalized for $\beta$-Tubulin. *, $\mathrm{p}<0.05$; **, $\mathrm{p}<0.005$; ***, $\mathrm{p}<0.0005$. 
a
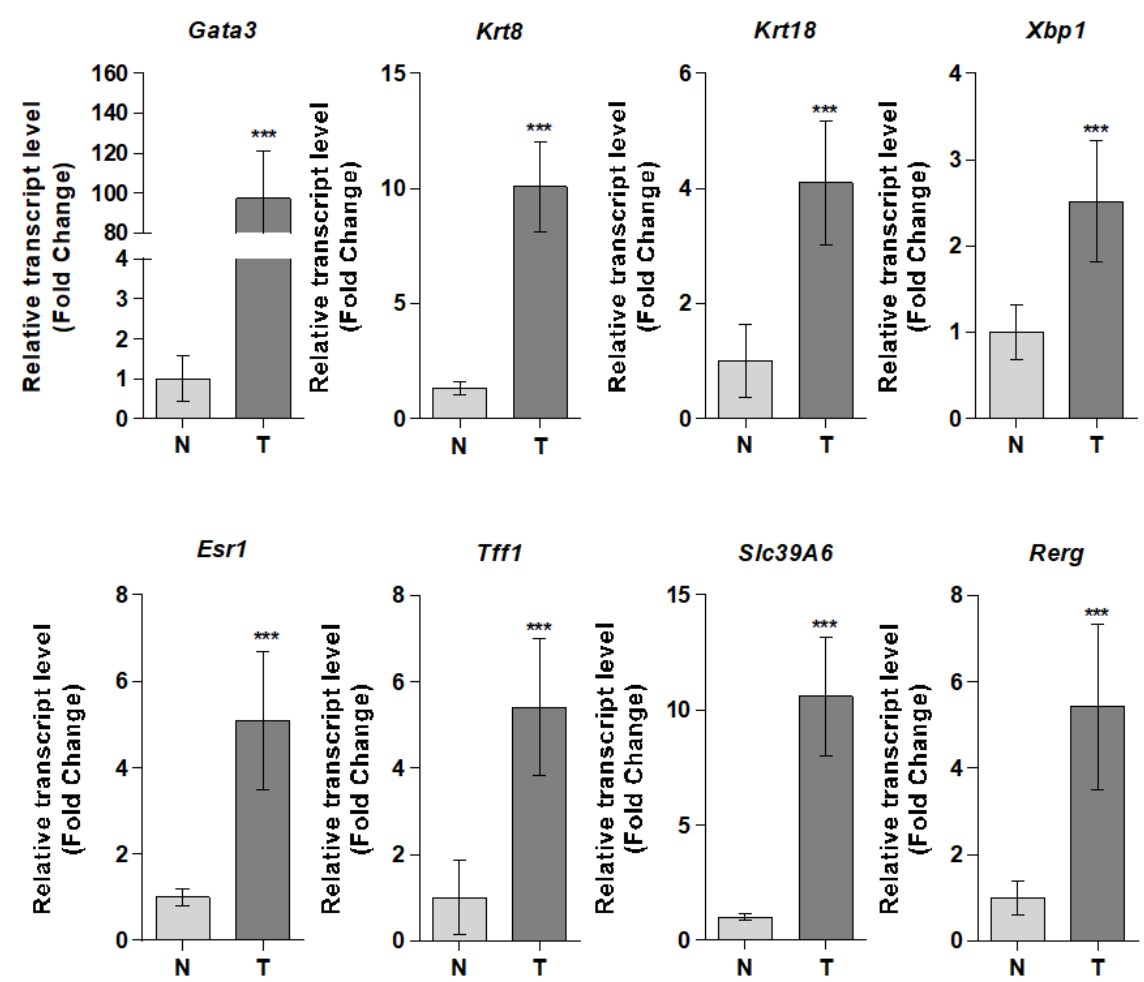

b
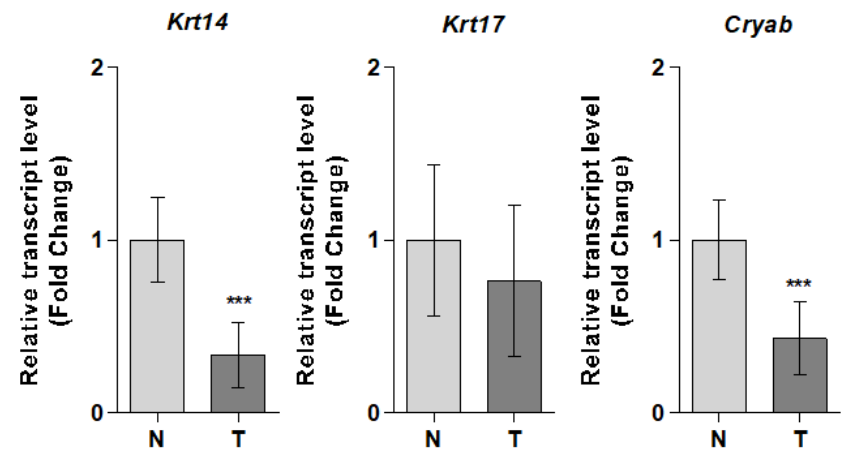

C

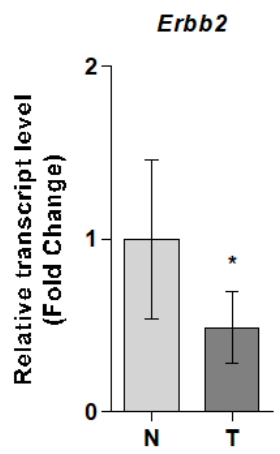

FIGURE 3

Figure 3: Transcript level of key genes encoding luminal and basal marker in mammary carcinoma. qRT-PCR of (a) luminal (Gata3, Krt8, Krt18, Xbpl and Esrl), ER $\alpha$ target (Tffl, Slc39a6 and Rerg), (b) basal (Krt14, Krt17 and Cryab) and (c) Erbb2 genes in 6 mammary tumors (T). The histograms represent the mean \pm SEM of 3 separate experiments and expressed as fold change vs control mammary gland $(\mathrm{N}) . *, \mathrm{p}<0.05 ; * * *, \mathrm{p}<0.0005$. 
a
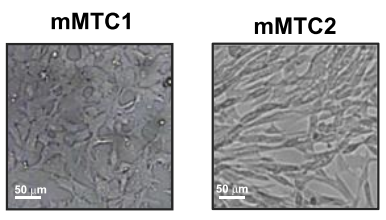

C

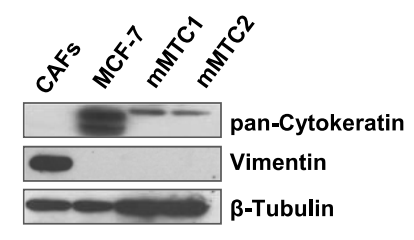

b

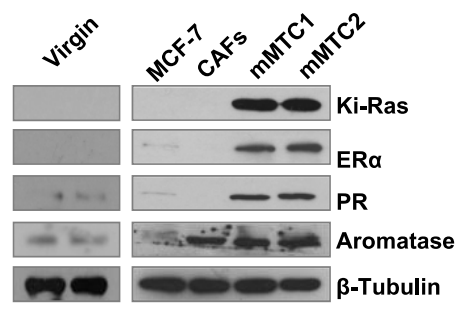

d

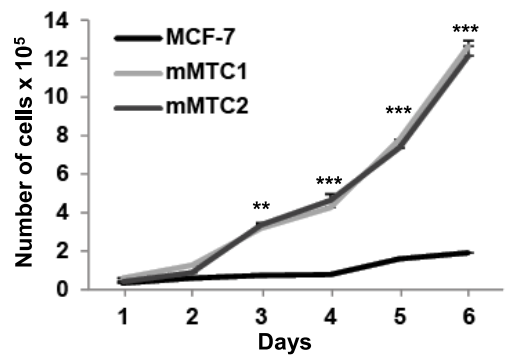

FIGURE 4

Figure 4: Characterization of mouse mammary tumor cell lines derived from MG-KiRas $^{(\mathbf{G 1 2 V})}$ tumors. (a) Phase contrast microscopy (10X) for mMTC1 and mMTC2 cells. (b) Immunoblotting of mMTC1 and mMTC2 cell extracts with antibodies directed against Ki-Ras, $\mathrm{ER} \alpha, \mathrm{PR}$, and Aromatase. $\beta$-Tubulin was used as a loading control. Protein extracts from mammary gland of virgin mice, cancer-associated fibroblasts (CAFs) and human MCF-7 breast cancer cell line were used as controls. (c) Immunoblotting of mMTC1 and mMTC2 cell extracts with antibodies directed against cytokeratins and Vimentin. $\beta$-Tubulin was used as a loading control. CAFs and MCF-7 cell line were used as positive controls. (d) Growth kinetics of mMTC1, mMTC2 and MCF-7 cells. **, $\mathrm{p}<0.005 ; * * *, \mathrm{p}<0.0005$. 

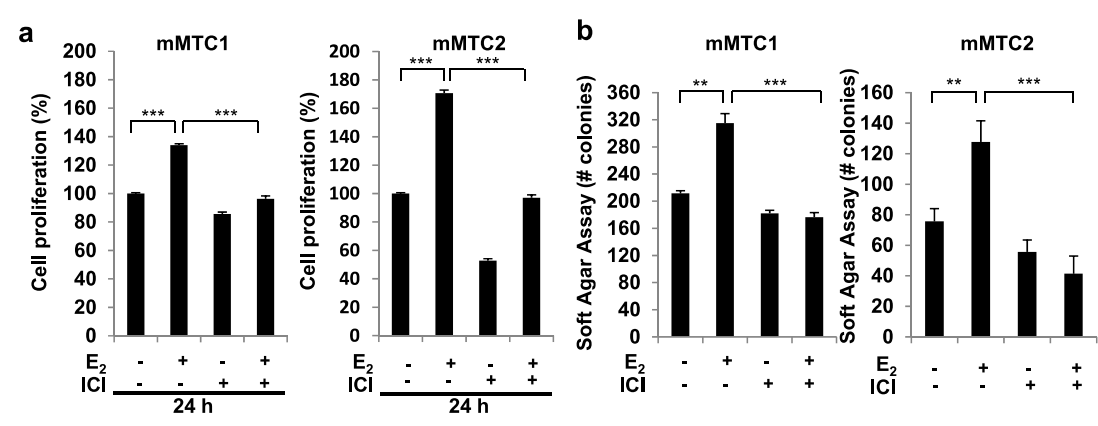

C
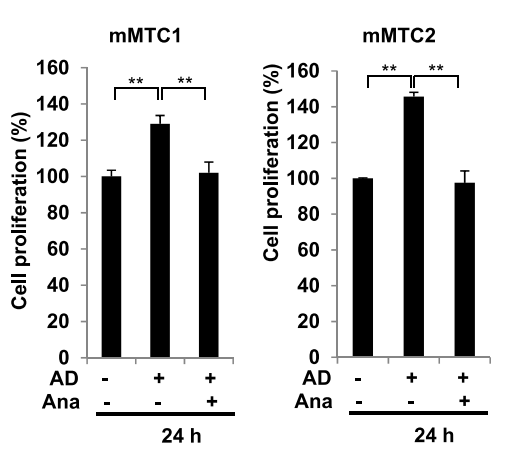

d

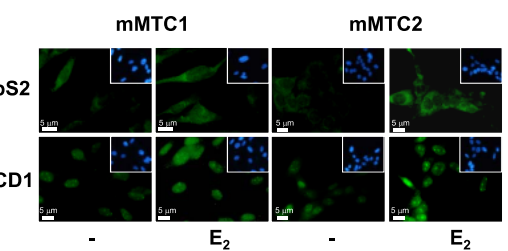

e
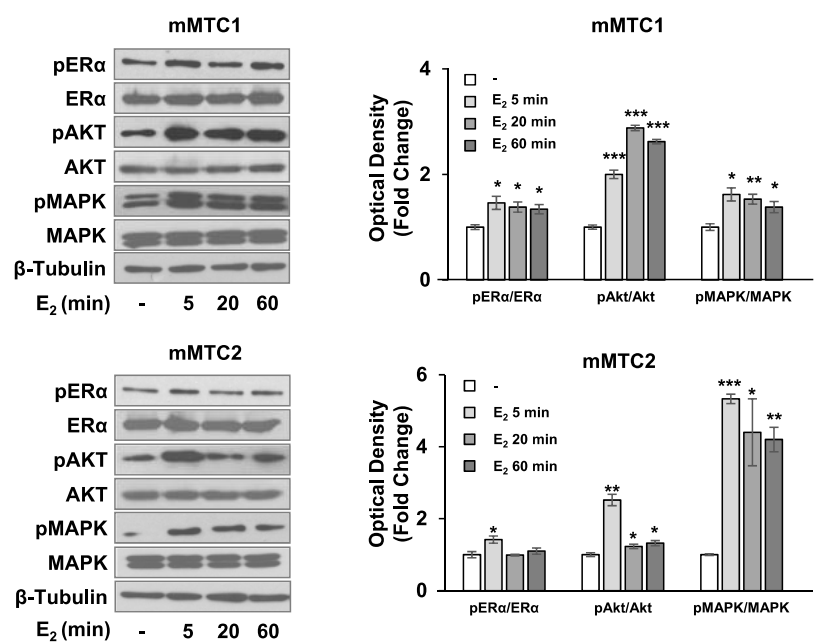

FIGURE 5

Figure 5: Estrogen sensitivity in mMTC1 and mMTC2 mouse mammary tumor cell lines. Proliferation evaluated by trypan blue cell count (a) and soft agar growth (b) assays of cells treated with 17ß-estradiol $\left(\mathrm{E}_{2}\right)$ and the antiestrogen ICI 182780 (ICI), as indicated. (c) Proliferation evaluated by trypan blue cell count assays of cells treated with 4-androstene-3,17-dione (AD) and/or Anastrozole (Ana) as indicated. (d) Immunofluorescence showing pS2 and Cyclin D1 (CD1) expression in cells treated with vehicle (-) or $\mathrm{E}_{2}$ for $24 \mathrm{~h}$, as indicated. Insets: DAPI staining for nuclei detection. (e) Immunoblotting for phospho(p)- ER $\alpha$ (Ser118), p-Akt (Ser473), p-MAPK (Thr202/Tyr204) levels and total proteins in mMTC1 and mMTC2 cells treated with vehicle (-) or $\mathrm{E}_{2}$ for 5, 20 and 60 minutes, as indicated. $\beta$-Tubulin was used as a loading control. The histograms represent the mean \pm SEM of three separate experiments in which band intensities were evaluated in terms of optical density arbitrary units (OD) and expressed as fold change in phosho/total/ $\beta$ Tubulin ratio relative to vehicle-treated samples. ${ }^{*}, \mathrm{p}<0.05 ; * *, \mathrm{p}<0.005 ; * * *, \mathrm{p}<0.0005$. 
a

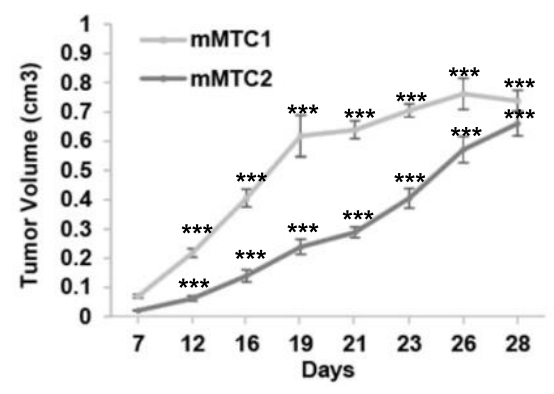

C

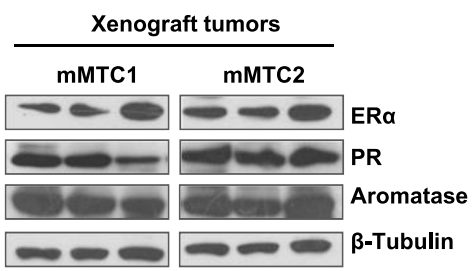

e

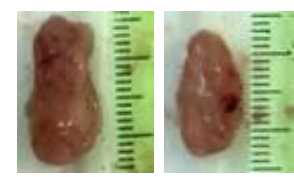

Vehicle

ICI
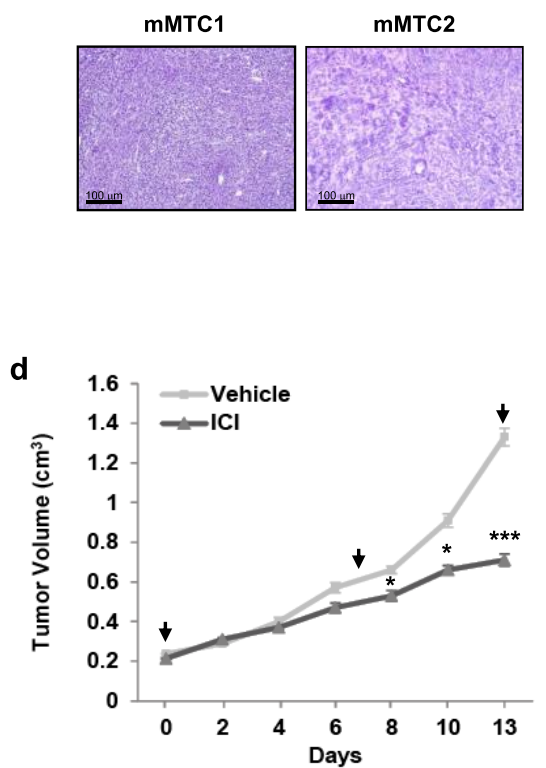

f

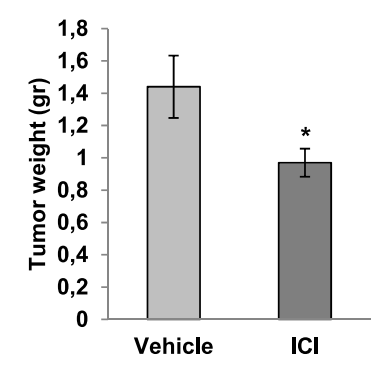

FIGURE 6

Figure 6: Xenograft tumor growth of mMTC1 and mMTC2 mouse mammary tumor cell lines.

(a) mMTC1 and mMTC2 cells were injected in ovariectomized female nude mice supplemented with 17 $\beta$-estradiol ( 8 mice per group) and tumor growth was monitored over time. (b) H\&E-stained histologic images of mMTC1 and mMTC2 xenograft tumors taken at day 28. (c) Immunoblotting of $\mathrm{ER} \alpha, \mathrm{PR}$ and Aromatase from mMTC1 and mMTC2 xenograft tumors. $\beta$-Tubulin was used as a loading control. (d) mMTC2 cells were injected into ovariectomized nude mice supplemented with 17 $\beta$-estradiol (8 mice/group) and treated with ICI 182780 (arrows). Tumor growth was monitored over time. (e) Images of a representative individual tumor from each treatment group at day 17, and (f) average tumor weight from vehicle and ICI-treated mice. ${ }^{*}, \mathrm{p}<0.05 ; * *, \mathrm{p}<0.0005$. 
a

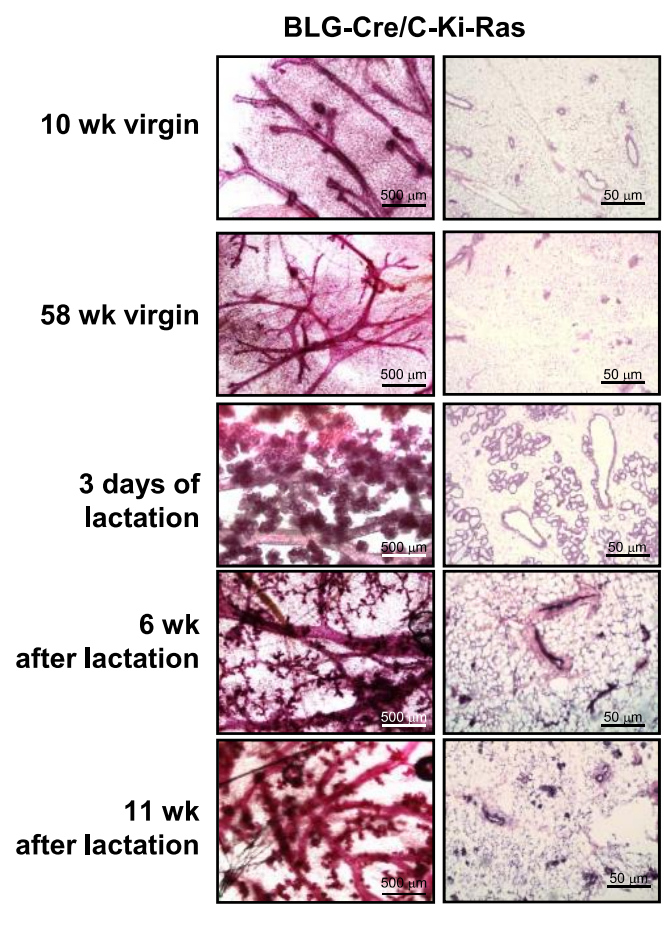

b

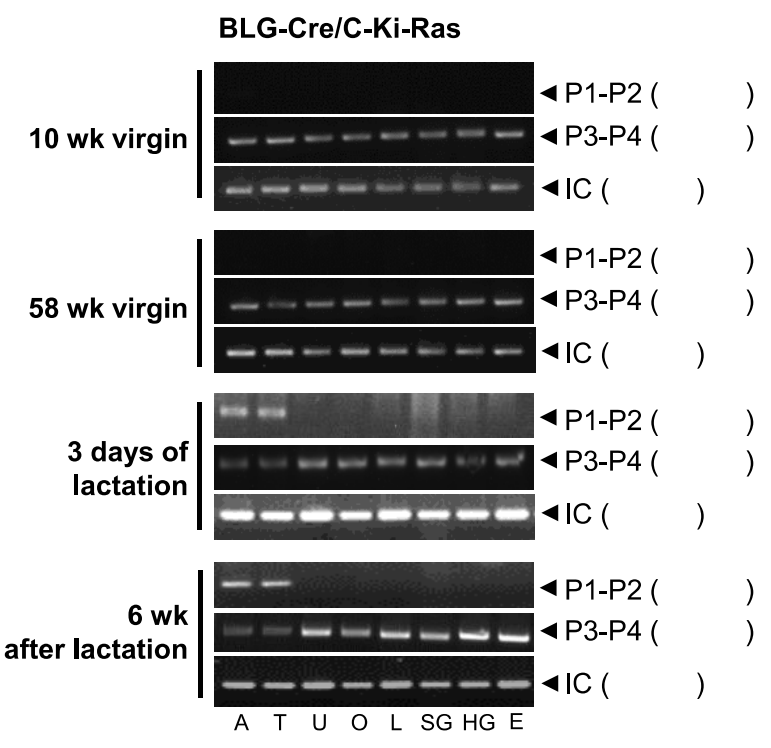

Supplementary Figure 1: Characterization of transgenic mice expressing Ki-Ras ${ }^{\left({ }^{(G 12 V}\right)}$ selectively in the mammary epithelium after lactation. (a) Representative picture of a carmine alum-stained whole mount mammary gland of virgin BLG-Cre/C-Ki-Ras ${ }^{(\mathrm{G} 12 \mathrm{~V})}$ mice and H\&E-stained sections, as well as during and after lactation, as indicated. (b) PCR analysis of DNA isolated from the indicated tissues to analyze Cre-mediated recombination by using $\mathrm{P} 1$ and $\mathrm{P} 2$ primers and the presence of EGFP stop cassette by using P3 and P4 primers. IC, internal control. A, abdominal mammary gland; $T$, thoracic mammary gland; $U$, uterus; O, ovary; L, lung; SG, salivary gland; HG, harderian gland; E, ear. 